\title{
NUDT18 catalyzes hydrolysis of active metabolites of the antivirals
}

\section{Remdesivir and Ribavirin}

\author{
Ann-Sofie Jemth ${ }^{1}{ }^{*}$, Emma Rose Scaletti $^{3}$, Evert Homan ${ }^{1}$, Pål Stenmark ${ }^{3}$, Thomas Helleday ${ }^{1,2}$, and Maurice \\ Michel $^{1^{*}}$ \\ ${ }^{1}$ Science for Life Laboratory, Department of Oncology-Pathology, Karolinska Institutet, 171 65, Solna, \\ Sweden. \\ ${ }^{2}$ Weston Park Cancer Centre, Department of Oncology \& Metabolism, Medical School, University of \\ Sheffield, S10 2RX, Sheffield, United Kingdom. \\ ${ }^{3}$ Department of Biochemistry \& Biophysics, Stockholm University, 106 91, Stockholm, Sweden. \\ *Corresponding authors; e-mail: ann-sofie.jemth@ki.se, maurice.michel@ki.se
}

\begin{abstract}
Remdesivir (GS-5734) has gained considerable interest due to its activity against replication of SARS-CoV2. Remdesivir is a broad-spectrum antiviral prodrug that is hydrolyzed intracellularly and phosphorylated by cellular kinases to its active triphosphate form (Remdesivir-TP). Here we tested Remdesivir-TP as a substrate for a panel of human hydrolases and found that NUDIX hydrolase 18 (NUDT18) catalyzes the hydrolysis of Remdesivir-TP. NUDT18 is expressed in respiratory epithelial cells suggesting that NUDT18 may limit the antiviral efficacy of Remdesivir by decreasing the intracellular concentration of its active metabolite at its intended site of action. The $k_{c a t}$ of NUDT18 for Remdesivir-TP was determined to $2.6 \mathrm{~s}^{-1}$ and the $K_{m}$ value was $156 \mu \mathrm{M}$, suggesting that NUDT18 catalyzed hydrolysis occurs in cells. In addition, we found that the triphosphate of the antiviral Ribavirin, with broad-spectrum activity against several RNA and DNA viruses, was hydrolyzed by NUDT18, albeit with a lower efficiency compared to Remdesivir-TP. NUDT18 activity was also tested with the triphosphates of the antivirals Sofosbuvir and Aciclovir for which low activity, in comparison to activities with Remdesivir-TP and Ribavirin-TP, was detected. These results suggest that NUDT18 can act as a cellular sanitizer and may influence the antiviral efficacy of Remdesivir and Ribavirin.
\end{abstract}

\section{Introduction}

The recent SARS-CoV-2 pandemic with its fast worldwide spread and high mortality rate has led to major efforts to repurpose already approved antiviral drugs in order to quickly control the outbreak and thereby save lives. Remdesivir (GS-5734) was originally developed for the treatment of Ebola but is a broad-acting antiviral which reduces the replication of coronaviruses both in cell culture and animal models (1). Remdesivir treatment was shown to decrease the severity of disease after MERS-CoV infection via decreasing virus replication and thereby reducing damage to the lungs when administered both before and after infection in a rhesus macaque model (1). Recently, Remdesivir has been tested in several clinical trials for treatment of COVID-19 caused by the corona virus SARS-CoV2. Remdesivir was shown to shorten the recovery time in hospitalized adults with COVID-19 as well as reducing mortality rate (2) and suggested to be most effective if administered early after infection (3). Remdesivir was approved for treatment of severe COVID-19 in July 2020 by the European Medicine Agency and later in the fall by the U.S Food and Drug Administration. (2,4-6). Remdesivir is a prodrug in form of a protected phosphate that upon cell entry (Figure 1, step 1) is metabolized by cellular enzymes to the corresponding phosphate (GS 441524, 
Figure 1, step 2). Subsequently, the monophosphate is further phosphorylated by cellular kinases to its active triphosphate form (Remdesivir-TP, aka GS-443902, Figure 1, step 3). The antiviral effect of Remdesivir-TP is mediated through its incorporation into the growing virus RNA chain by the viral RNA dependent RNA polymerase (RdRp, Figure 1, step 4). The incorporated Remdesivir metabolite escapes the viral proofreading system and causes the polymerase to stall and RNA replication to be terminated (Figure 1 , step 5) leading to a decrease in viral RNA $(7,8)$.

Ribavirin is another antiviral drug that was tested for activity towards SARS-COV2. Ribavirin has since the seventies been known as a broad-spectrum antiviral of both DNA and RNA viruses (9). It has been used in combination with IFN- $\alpha$-based therapy to treat hepatitis $C(10)$ as well as other viral infections such as Lassa fever (11), Crimean-Congo fever $(12,13)$ and chronic hepatitis E virus infections (14). Ribavirin in combination with IFN- $\beta$ was shown to synergistically inhibit SARS-associated coronavirus replication in animal and human cell lines (15) suggesting that Ribavirin could be a potential treatment option for SARSCoV2. The precise mode of action of Ribavirin is not completely understood and its metabolites have been suggested to target several processes of which the antiviral impact may depend on their intracellular concentrations (16). Ribavirin-MP inhibits inosine monophosphate dehydrogenase leading to GTP depletion with effects on many cellular processes. Ribavirin-TP has been hypothesized to directly inhibit viral RNA dependent polymerase and may at higher concentrations also cause mutations in the viral genome. Ribavirin-TP is hydrolyzed by the ITPase hydrolase and patients carrying alleles encoding low activity ITPase variants display a reduced risk of hepatitis $C$ relapse suggesting that these patients have higher concentrations of the active Ribavirin metabolite. Furthermore, low activity ITPase alleles have been shown to protect against anemia upon INF $\alpha$ and Ribavirin therapy $(16,17)$.

The ITPase activity dependent outcome of Ribavirin treatment strongly emphasizes the impact of cellular metabolism on drug efficiency. Similar to ITPase several NUDIX enzymes catalyze the hydrolysis of modified nucleoside triphosphates $(18,19)$ and have been shown to modulate the efficacy of various drugs including antivirals $(20,21)$. An example is NUDT15 that we recently reported catalyzes the hydrolysis of Ganciclovir-TP. Similarly, hydrolysis of Remdesivir-TP into Remdesivir-MP catalyzed by a human nucleotide hydrolase (Figure 1, Step 6) would reduce the cellular concentration of the active Remdesivir metabolite. Conversion of Remdesivir-MP to the corresponding nucleoside through the action of $5^{\prime}$ nucleotidase would enable transport out from the cell (Figure 1, Step 7) and further decrease the antiviral potency of Remdesivir.

In order to investigate if such a hydrolase could be found within the NUDIX family of enzymes we tested Remdesivir-TP as a substrate for a panel of human NUDIX hydrolases and found that NUDT18 catalyzed the hydrolysis of Remdesivir-TP. Encouraged by this we tested NUDT18 for activity with several antiviral triphosphates and found NUDT18 to also catalyze the hydrolysis of Ribavirin-TP. NUDT18 has to date only been described to display activity towards 8-oxo-GDP. It has therefore been suggested to cleanse the nucleotide pool from oxidatively damaged nucleotides, preventing their incorporation into DNA $(22,23)$. The results of this study suggest that NUDT18 acts as a cellular sanitizer that contributes to removing modified nucleotides of both endogenous and exogenous origin, and potentially modulates the efficiency of the antiviral drugs Remdesivir and Ribavirin.

\section{Materials and methods}

\section{Protein production}

MTH1, NUDT15, NUDT18, NUDT5 and NUDT9, and E. coli PPase were produced as N-terminally His-tagged proteins and were expressed and purified by the Protein Science Facility, Karolinska Institute, using NiIMAC (HisTrap HP, GE Healthcare) followed by gel filtration (HiLoad 16/60 Superdex 75 or HiLoad 16/60 Superdex 100, GE Healthcare) as previously described (24). Proteins were concentrated and then stored 
as aliquots at $-80^{\circ} \mathrm{C}$ in storage buffer $(20 \mathrm{mM}$ HEPES pH 7.5, $300 \mathrm{mM} \mathrm{NaCl}, 10 \%$ glycerol and $0.5 \mathrm{mM}$ TCEP (tris-(carboxyethyl)phosphine)). ITPase, dUTPase and dCTPase were produced as N-terminally His-tagged proteins and expressed and purified as earlier described (25).

\section{Screen of human hydrolases for Remdesivir-TP activity}

Hydrolysis activity of MTH1, NUDT15, NUDT18, NUDT5 and NUDT9 (200 nM) with $100 \mu$ M Remdesivir-TP was assayed in reaction buffer ( $20 \mathrm{mM}$ TrisAcetate $\mathrm{pH} 8.0,40 \mathrm{mM} \mathrm{NaCl}, 10 \mathrm{mM} \mathrm{MgAc}, 1 \mathrm{mM}$ DTT, 0.01\% Tween20) by incubating reaction mix in wells of 96 -well plates (NUNC) at $22^{\circ} \mathrm{C}$ for 30 minutes. Formed Pi was detected by addition of malachite green reagent (26) and measurement of absorbance at $630 \mathrm{~nm}$. Activity of $200 \mathrm{nM}$ MTH1, NUDT15, NUDT18 and NUDT5, with $100 \mu \mathrm{M}$ Remdesivir-TP was also tested in the presence of E. coli PPase $(0.2 \mathrm{U} / \mathrm{ml})$ which converts formed PPi to Pi. Activity of the human pyrophoshates: ITPase, dUTPase and dCTPase with $100 \mu \mathrm{M}$ Remdesivir-TP in the presence of PPase was assayed and compared to activity of NUDT18 with $100 \mu \mathrm{M}$ 8-oxo-dGDP in the presence and absence of $0.2 \mathrm{U} / \mathrm{ml}$ PPase. Buffer controls with and without PPase were included and the background signal was subtracted from the assay data.

\section{Assessment of specific activity of NUDT18 with Remdesivir-TP, Ribavirin-TP and 8-oxo-dGDP}

In order to test if NUDT18 can also hydrolyze Ribavirin-TP and to compare its activity towards RemdesivirTP (BioCarbosynth) and 8-oxo-dGDP, $100 \mu \mathrm{M}$ Ribavirin-TP (Jena Bioscience), Remdesivir-TP or 8-oxodGDP, respectively, was incubated with $10 \mathrm{nM}$ NUDT18 in reaction buffer (20 mM TrisAcetate pH 8.0, 40 $\mathrm{mM} \mathrm{NaCl}, 10 \mathrm{mM} \mathrm{MgAc}, 1 \mathrm{mM}$ DTT, 0.01\% Tween20) fortified with $0.2 \mathrm{U} / \mathrm{ml}$ PPase for 30 minutes at 22 ${ }^{\circ} \mathrm{C}$ after which formed $\mathrm{Pi}$ was detected by addition of malachite green reagent and measurement of absorbance at $630 \mathrm{~nm}$ in a Hidex spectrophotometer.

\section{Determination of kinetic parameters of NUDT18 with Remdesivir-TP and Ribavirin-TP} Initial rates of NUDT18 were determined in assay buffer $(20 \mathrm{mM}$ TrisAcetate $\mathrm{pH} 8.0,40 \mathrm{mM} \mathrm{NaCl}, 10 \mathrm{mM}$ MgAc, $1 \mathrm{mM}$ DTT, $0.01 \%$ Tween20, $0.2 \mathrm{U} / \mathrm{ml}$ PPase) at concentrations ranging from 0 to $300 \mu \mathrm{M}$ for Remdesivir-TP and from 0 to $200 \mu \mathrm{M}$ for Ribavirin-TP, using $10 \mathrm{nM}$ NUDT18. Reaction mixture was incubated for 0,10 or 20 minutes. Formed $\mathrm{Pi}$ was detected by adding malachite green reagent and measurement of absorbance at $630 \mathrm{~nm}$. A Pi standard curve was included on the plate and used to convert absorbance to concentration Pi. Enzyme saturation curves were also produced with 8-oxo-dGDP, which has been described to be the endogenous substrate of NUDT18, using the same enzyme concentration and buffer conditions. 8-oxo-dGDP concentrations ranging between 0 and $100 \mu \mathrm{M}$ were used. Initial rates were calculated using linear regression and plotted against substrate concentration. The MichaelisMenten equation was fitted to the data points and kinetic parameters of NUDT18 were determined using GraphPad Prism 8.0. Data points were measured in duplicate and two independent experiments were performed.

\section{Assessment of specific activity of NUDT18 with triphosphates of other antivirals}

The finding that NUDT18 displays pronounced activity with the antiviral triphosphates Remdesivir-TP and Ribavirin-TP prompted us to also test the activity of NUDT18 with an expanded panel of antiviral triphosphates that are considered to be the active antiviral metabolite. The panel included the triphosphate of Sofosbuvir used for the treatment of hepatitis C (Sofosbuvir-TP, (2R)-(2'-deoxy-2'-fluoro2-methyl-uridine-5'-TP, Sierra bioresearch), the triphosphate of Ganciclovir used to treat cytomegalovirus infection treatment (Ganciclovir-TP, Sierra bioresearch) and the triphosphate of Aciclovir used for Herpes simplex virus infection therapy, (Aciclovir-TP, Sierra bioresearch). We also included the active metabolite of the cytostatic drug gemcitabine (Gemcitabine-TP, Sierra bioresearch). NUDT18 (20 nM) was incubated with $100 \mu \mathrm{M}$ of Ganciclovir-TP, Aciclovir-TP, Sofosbuvir-TP and Gemcitabine-TP for 30 min at $22^{\circ} \mathrm{C}$ in assay 
buffer (20 mM TrisAcetate pH 8.0, $40 \mathrm{mM} \mathrm{NaCl}, 10 \mathrm{mM}$ Magnesium Acetate, $1 \mathrm{mM}$ DTT and 0.01\% Tween 20 ), in absence and presence of PPase $0.2 \mathrm{U} / \mathrm{ml}$. Formed Pi was detected by addition of malachite green reagent followed by measurement of absorbance at $630 \mathrm{~nm}$.

\section{Determination of kinetic parameters of NUDT18 with triphosphates of antiviral compounds}

Initial rates of NUDT18 $(10 \mathrm{nM})$ were determined in assay buffer $(20 \mathrm{mM}$ TrisAcetate $\mathrm{pH} 8.0,40 \mathrm{mM} \mathrm{NaCl}$, $10 \mathrm{mM}$ MgAc, $1 \mathrm{mM}$ DTT, 0.01\% Tween20, $0.2 \mathrm{U} / \mathrm{ml}$ PPase at concentrations ranging from 0 to $300 \mu \mathrm{M}$ for Sofosbuvir-TP and Aciclovir-TP by incubating the reactions for 0, 10, 20 and 30 minutes. Formed Pi was detected by adding malachite green reagent and measurement of absorbance at $630 \mathrm{~nm}$. The concentration of formed Pi was calculated using a Pi standard curve included on the assay plate. Enzyme saturation curves were also produced for dGTP using a concentration range between 0 and $200 \mu \mathrm{M}$. Initial rates were plotted against substrate concentration and the Michaelis-Menten equation was fitted to the data points allowing kinetic parameters of NUDT18 to be determined. Data points were measured in duplicate and two independent experiments were performed.

\section{Computational analysis}

All calculations were performed using Schrödinger Suite 2021-1 [Schrödinger LLC, New York, NY, 2021]. Protein structure preparation. The apo structure of human NUDT18 (3GG6.pdb, unpublished) was prepared using the Protein Preparation Wizard. Briefly, the raw PDB structure was processed by automatically assigning bond orders, adding hydrogens, converting seleno-methionine to methionine, adding missing side chains, and creating possible disulfide bridges. Residues with alternate positions were locked in the conformations with the highest average occupancy. Hydrogen bonding networks were optimized automatically by optimization of hydroxyls, Asn, Gln, and His residue states using ProtAssign. A restrained minimization was then performed using the OPLS4 force field, until an RMSD convergence of $0.30 \AA$ was reached for the heavy atoms.

Binding site analysis. SiteMap was used to probe the prepared NUDT18 structure for possible ligand binding sites. The 5 top-ranked potential binding sites were identified. At least 15 site points per reported sites were required. The more restricted definition of hydrophobicity together with a standard grid $(0.7$ $\AA$ ) were used. Site maps at $4 \AA$ A or more from the nearest site points were cropped.

Ligand structure preparation. The structure of Remdesivir-TP was copied as isomeric smiles from PubChem (CID: 56832906) and pasted as 3D structure into Maestro. Ligprep was then used to prepare the structure of Remdesivir-TP for docking. The OPLS4 force field was used for minimizations; possible ionization states at $\mathrm{pH} 7.0 \pm 2.0$ were generated using Epik, and possible tautomers were generated; specified chiralities were retained and at most 1 stereoisomer was generated.

Induced-fit docking. Remdesivir-TP was docked to NUDT18 using the Induced-Fit Docking protocol (27). The site points of largest site identified by SiteMap were used to center the docking boxes. The size of the enclosing box was set to $20 \AA$. Glide XP was used for the redocking step, otherwise all settings were kept at default values.

\section{Inhibition assay}

Since Remdesivir-TP acts as a substrate of NUDT18 we decided to investigate if Remdesivir or its metabolites act as inhibitors of NUDT18 or its close relatives NUDT15 and MTH1. Activity of MTH1 (10 $\mathrm{nM})$ and NUDT15 (10 nM) was tested in assay buffer (0.1 M TrisAcetate pH 7.5, $40 \mathrm{mM} \mathrm{NaCl}, 1 \mathrm{mM}$ DTT, $10 \mathrm{mM}$ MgAcetate) fortified with PPase $(0.2 \mathrm{U} / \mathrm{ml})$, with $100 \mu \mathrm{M}$ dGTP in the presence of $1 \%$ DMSO or with $100 \mu \mathrm{M}$ of Remdesivir-TP (\#G167050, BioCarbosynth), Remdesivir (\#AG170167, BioCarbosynth) or Remdesivir metabolite (\#AG167808, BioCarbosynth). NUDT18 activity was assayed using 100 nM NUDT18 and $100 \mu \mathrm{M}$ 8-oxo-dGDP in assay buffer. The reaction mixture was incubated for $30 \mathrm{~min}$ at $22^{\circ} \mathrm{C}$ after 
which formed $\mathrm{Pi}$ was detected by addition of malachite green reagent followed by absorbance measurements at $630 \mathrm{~nm}$ in a Hidex spectrophotometer.

\section{Results and discussion}

\section{NUDT18 catalyzes the hydrolysis of Remdesivir-TP and Ribavirin-TP}

In order to investigate if human NUDIX enzymes can modulate the cellular concentration of the active metabolite of Remdesivir and thereby reduce its efficacy as an antiviral drug we tested human MTH1, NUDT15, NUDT18, NUDT5 and NUDT9 for hydrolysis activity with Remdesivir-TP. Among the human NUDIX hydrolases tested only NUDT18 was found to catalyze the hydrolysis of Remdesivir-TP (Figure 2A). NUDT18 was shown to catalyze the hydrolysis of the bond between the $\alpha$-and $\beta$-phosphate groups as well as the bond between the $\beta$ - and $\gamma$-phosphate groups (Figure 2A and B) as evidenced by an increase in the amount of Pi formed in the presence of PPase, which hydrolyzes PPi. Based on the described activity of ITPase with Ribavirin-TP, an active metabolite of the antiviral Ribavirin, we argued that ITPase may also hydrolyze other antiviral triphosphates. Thus, we tested human ITPase as well as the human hydrolases dCTPase and dUTPase for activity with Remdesivir-TP. Human dCTPase displayed low but measurable activity with Remdesivir-TP while no activity was detected with dUTPase or ITPase (Figure 2C). Comparison with NUDT18 activity towards 8-oxo-dGDP showed an approximately 2-fold higher specific activity compared to Remdesivir-TP at $100 \mu \mathrm{M}$ substrate concentration (Figure $2 \mathrm{C}$ ).

The observed activity of NUDT18 with Remdesivir-TP prompted us to also test Ribavirin-TP as a substrate for NUDT18. We found that Ribavirin-TP is also hydrolyzed by NUDT18, albeit not to the same extent as Remdesvir-TP (Figure 3). Similar to Remdesivir-TP, Ribavirin-TP is hydrolysed to both the corresponding di- and monophosphate, as shown by an increase in the signal when PPase was included in the assay buffer (Figure 3). In comparison with 8-oxo-dGDP the specific activity of NUDT18 is lower for both Remdesvir-TP and Ribavirin-TP. To investigate the activity of NUDT18 with Remdesivir-TP and RibavirinTP in more detail we performed kinetic analyses of the NUDT18-catalyzed reactions using Remdesivir-TP, Ribavirin-TP and 8-oxo-dGDP by producing enzyme saturation curves (Figure 4A, B and C). We determined kinetic parameters for these substrates under identical conditions (Figure 4F). The $K_{m}$ value for NUDT18 was determined to be $16.5 \mu \mathrm{M}$ for 8-oxo-dGDP, which is comparable with a previously published $\mathrm{K}_{\mathrm{m}}$-value of $12 \mu \mathrm{M}(22)$. The $\mathrm{k}_{\text {cat }}$ value for 8 -oxo-dGDP at $22^{\circ} \mathrm{C}$ was determined to be $1.8 \mathrm{~s}^{-1}$ and the calculated $\mathrm{k}_{\text {cat }} / \mathrm{K}_{\mathrm{m}}$ value was $109,800 \mathrm{M}^{-1} \mathrm{~s}^{-1}$. The $\mathrm{K}_{\mathrm{m}}$ value for Remdesivir-TP was determined to be $156 \mu \mathrm{M}(\mathrm{n}=2)$ and the $\mathrm{k}_{\text {cat }}$ value was $2.6 \mathrm{~s}^{-1}$ resulting in a $\mathrm{k}_{\mathrm{cat}} / \mathrm{K}_{\mathrm{m}}$ value of $17,700 \mathrm{M}^{-1} \mathrm{~s}^{-1}$. The approximately 6 -fold higher specificity constant $\left(\mathrm{k}_{\mathrm{cat}} / \mathrm{K}_{\mathrm{m}}\right.$ value) of NUDT18 for 8-oxo-dGDP implies that 8-oxo-dGDP would be the preferred substrate over Remdesivir-TP at the same concentration. However, the concentration of Remdesivir in monkey lung cell tissue post IV administration is estimated to be $800 \mathrm{nM}$ (28). Based on an estimation of the intracellular 8-oxo-dGTP concentration of $2 \mathrm{nM}$ in U2OS cells (29), and the assumption that the cellular concentration of 8-oxo-dGDP likely is in a similar range or lower, one can conclude that the cellular Remdesivir-TP concentration is likely to be at least 100-fold higher than the concentration of 8-oxo-dGDP in vivo. This suggests that the activity of NUDT18 with Remdesivir-TP may be of relevance for modulating the Remdesivir-TP concentration in cells.

When comparing Remdesivir-TP and Ribavirin-TP as substrates for NUDT18, Remdesivir-TP appears to be the preferred substrate. NUDT18 displays a $k_{\text {cat }}$ value for Ribavirin-TP hydrolysis that is approximately $1 \mathrm{~s}^{-}$ ${ }^{1}$ and a $\mathrm{K}_{\mathrm{m}}$-value of $111 \mu \mathrm{M}$, resulting in a catalytic efficiency value of $8,800 \mathrm{~s}^{-1} \mathrm{M}^{-1}$, which is approximately half of the corresponding value for Remdesivir-TP (Figure 4F). Comparison of the kinetic parameters of Remdesivir-TP and Ribavirin-TP with those for 8-oxo-dGDP show that the difference primarily lies in the $\mathrm{K}_{\mathrm{m}}$ value suggesting a better fit of 8-oxoguanine in the active site of NUDT18. 


\section{NUDT18 catalyzes the hydrolysis of other antiviral triphosphates}

In order to investigate if NUDT18 can catalyze the hydrolysis of other antiviral triphosphates we expanded the substrate screen of NUDT18 to include several antiviral triphosphates. We found that Sofosbuvir-TP, Aciclovir-TP, Ganciclovir-TP as well as Gemcitabin are also hydrolyzed by NUDT18 to some extent. Similar to the NUDT18-catalyzed hydrolysis of Remdesivir-TP and Ribavirin-TP, hydrolysis takes place at both the $\beta-\gamma$ and the $\alpha-\beta$ phosphate bonds in these substrates with approximately $50 \%$ of the hydrolysis taking place at each of these positions (Figure 4D). Kinetic analysis revealed that the activity with Aciclovir-TP, the best substrate in this panel of substrates, is much lower compared to the activity with Remdesivir-TP with a $\mathrm{k}_{\text {cat }} / \mathrm{K}_{\mathrm{m}}$ value approximately 5 times lower (Figure $4 \mathrm{E}$ and $\mathrm{F}$ ). However, the $\mathrm{k}_{\text {cat }} / \mathrm{K}_{\mathrm{m}}$ value was still 2.2 times higher than the corresponding $\mathrm{K}_{\text {cat }} / \mathrm{K}_{\mathrm{m}}$ value for dGTP. The fact that Aciclovir contains a guanine moiety like dGTP indicates that the higher activity of NUDT18 with Aciclovir-TP compared to dGTP lies in NUDT18 being able to better accommodate the nucleobase and the modified sugar part of Aciclovir-TP in the active site. This enables a positioning of the phosphate groups which is more productive for hydrolysis. This is reflected by a 2.6 times higher turnover number $\left(k_{\text {cat }}\right)$ for Aciclovir-TP compared to dGTP, while the $\mathrm{K}_{\mathrm{m}}$ values are comparable (Figure $4 \mathrm{~F}$ ). Whether the activity of NUDT18 with these antiviral triphosphates bears clinical relevance for modulating the potency of these antivirals needs further investigation.

\section{Investigation of binding mode in NUDT18}

Remdesivir-TP contains a nitrile group on the $\mathrm{C} 1$ atom of the ribose unit (Figure 5). The fact that none of the other tested NUDIX proteins displays any activity with Remdesivir-TP suggests that only the active site of NUDT18 is spacious enough and contains amino acids enabling accommodation of this moiety while still orienting the rest of the molecule allowing for efficient hydrolysis. To date two crystal structures of human NUDT18 have been disclosed (PDB IDs: 3gg6 and 4hvy), both comprising apo structures of truncated constructs covering residue positions 26-179. Analysis using SiteMap [SiteMap, Schrödinger, LLC, New York, NY, 2021] indicated that the largest pocket adjacent to the helix containing the NUDIX motif is relatively small and polar in comparison to other NUDIX family members (30). Docking of Remdesivir-TP to this site did not yield any good-scoring poses with plausible accommodation of the heterocyclic core of Remdesivir-TP. In comparison, the homologous NUDIX family members NUDT1 and NUDT15 contain deeper druggable pockets which readily accommodate nucleobases and small-molecule inhibitors $(25,31)$. This suggests that considerable conformational changes are required for NUDT18 to harbour the heterocyclic cores of Remdesivir-TP and other substrates. Attempts to induce a deeper hydrophobic pocket using an induced-fit procedure as described by Loving et al. (32) also failed to generate a pocket for Remdesivir-TP with significantly improved SiteScore.

In order to obtain structural information to understand the binding mode of NUDT18 substrates we carried out extensive crystallization trials of full length NUDT18 without added ligands or together with 8oxo-dGDP, Remdesivir-TP or Ribavirin-TP. This included seven different commercially available crystallization screens (JCSG+, INDEX, Morpheus, Morpheus II, Pact Premier, Structure Screen and SaltRX) using different protein concentrations (ranging from $5 \mathrm{mg} / \mathrm{mL}$ to $25 \mathrm{mg} / \mathrm{mL}$ ) and temperatures $\left(4{ }^{\circ} \mathrm{C}\right.$ and $20^{\circ} \mathrm{C}$ ). Unfortunately, we were not able to obtain crystals in any of the conditions tested. As only structures of the nucleosidase binding domain are available for NUDT18 it is possible that the second domain and linking region renders the full-length protein too flexible for crystallization. We performed a structural similarity search using the DALI web server (33), which indicated that hNUDT18 is most structurally similar to human and other eukaryotic MTH1 proteins from dogs, mice and zebrafish (with rms differences of 2.1 to $2.3 \AA$ ). As Remdesivir-TP is an analogue of ATP we were particularly interested in comparing the existing hNUDT18 nucleotidase domain structure (PDB ID: 3gg6) with structures of hMTH1 bound to N6-methyl-dAMP (PDB ID: 6qvo, (19) and 2OH-dATP (PDB ID: 5ghq, (34). Comparison of these structures showed that residues from the highly conserved NUDIX motif (GX5EX7REVXEEXGU) that 
coordinate the essential magnesium ions required for substrate hydrolysis superimpose nicely between the structures (Supplementary Figure 1A). This provides some level of certainty as to where the $\alpha$ phosphate group of Remdesivir-TP would be positioned in hNUDT18 and therefore the orientation of the ligand within the binding pocket. Analysis of the hNUDT18 reveals a shallow binding pocket (Supplementary Figure $1 \mathrm{~B}$ ) and structural rearrangements are clearly required to accommodate the adenine base. Analysis of N6-methyl-dAMP and 2OH-dATP binding in MTH1 shows that the residue W117* forms an important pi-stacking interaction with the adenine base. In NUDT18 the corresponding residue is an alanine, however a tyrosine residue (Y72, N33* in hMTH1) which would be capable of performing an equivalent pi-stacking interaction is situated in close proximity (Supplementary Figure $1 \mathrm{C}$ ). In the current NUDT18 apo structure Y72 clashes with the bound base when compared to the ligands in the hMTH1 structures. A conformational adjustment must occur in order to make room for the substrate. Repositioning of this tyrosine would shape the binding pocket in such a way that it, while still being shallow, is capable of accommodating N6-methyl-dAMP and 2OH-dATP and importantly, Remdesivir-TP with its additional nitrile group (Supplementary Figure 1D). The lower $\mathrm{K}_{m}$ value of 8-oxo-dGDP for NUDT18 suggests it fits better within the active site of the enzyme than Remdesivir-TP. In the absence of a fulllength NUDT18 structure, a structure of the NUDT18 nucleotidase domain bound to the natural substrate 8-oxo-dGDP or to Remdesivir-TP would be very useful for elucidating the exact structural rearrangements that occur within the nucleotide binding site upon binding of these ligands.

In an attempt to understand what structural features of the substrates determine their quality as NUDT18 substrate, we calculated the values of catalytic efficiency and turnover number of NUDT18 for the tested substrates relative to the corresponding values for dGTP. In addition, we examined the chemical structures of the tested substrates (Figure 5). NUDT18 has previously been reported to catalyze the hydrolysis of 8-oxo-dGDP and 8-oxo-GDP with the same efficiency (22), demonstrating that the 2'-OH group can be accommodated in the active site of NUDT18. This suggests a flexibility towards alterations within this part of the nucleoside substrate. Among the tested substrates, the turnover number is highest for Remdesivir-TP suggesting that either NUDT18 catalyzed hydrolysis or product release is faster for Remdesivir-TP compared to 8-oxo-dGDP under substrate saturating conditions. However, the $\mathrm{K}_{\mathrm{m}}$-value is considerably lower for 8-oxo-dGDP (Figure 4F), indicating specific interactions between the oxidized nucleobase and the active site of NUDT18. The lower $\mathrm{K}_{m}$ value, which translates into higher catalytic efficiency for 8-oxo-dGDP, may in part be due to nucleoside triphosphates binding with lower affinity to the active site compared to nucleoside diphosphates. The difference in catalytic efficiency between Remdesivir-TP and Ribavirin-TP can likely be attributed to differences in positioning for efficient hydrolysis and/or product release since their $\mathrm{K}_{\mathrm{m}}$ values are similar. Interactions between the nucleobase and/or the nitrile group of Remdesivir-TP and NUDT18 may contribute to a more productive binding. However, in absence of structural information, it is difficult to draw any conclusions about the binding mode. Nevertheless, the fact that the active site of NUDT18 can accommodate molecules with rather different structures and that hydrolysis takes place at two positions with equal efficiency indicates a relatively flexible binding mode for these substrates.

\section{Inhibition of NUDIX enzymes by Remdesivir and metabolites.}

Since Remdesivir-TP was found to be a substrate for NUDT18 we argued that Remdesivir and its metabolites may inhibit NUDT18 and related NUDIX proteins. We therefore tested MTH1 and NUDT15 for inhibition by Remdesivir, the Remdesivir metabolite GS 441524 (arising from cellular hydrolysis of Remdesivir) and Remdesivir-TP, and NUDT18 for inhibition by Remdesivir and GS 441524. NUDT15 was found to be modestly inhibited by $100 \mu \mathrm{M}$ Remdesivir (26\%) as well as by GS 441524 (21 \%) (Figure 6). MTH1 was slightly inhibited by GS 441524 (23\%) while no inhibition of NUDT18 by any of the tested Remdesivir compounds was observed. The modest inhibitory effect of Remdesivir and its metabolites 
imply that Remdesivir treatment is unlikely to have a pronounced effect on the cellular activity of these enzymes.

\section{Consequence of NUDT18 activity with antiviral triphosphates}

The results presented here suggest that NUDT18 can convert Remdesivir-TP to Remdesivir-DP and Remdesivir-MP in the cell. However, since Remdesivir-DP and Remdesivir-MP are substrates for adenylate kinase 2 they will be phosphorylated and a cellular equilibrium between production of Remdesivir-TP by kinases and hydrolysis catalyzed by NUDT18 is likely established. Furthermore, the action of intracellular 5'-nucleotidase may affect the concentration of Remdesivir-MP. For NUDT18 to play a clinically relevant role in modulating Remdesivir efficacy it has to be present in the cells that are infected by the virus. NUDT18 is ubiquitously expressed, displays low tissue specificity (https://www.proteinatlas.org/ENSG00000275074-NUDT18) and importantly is found in lung (https://www.ebi.ac.uk/gxa/home) and in respiratory epithelial cells. This suggests that NUDT18 would be able to modulate the effective concentration of Remdesivir-TP at its intended site of action. Potentially, inhibition of NUDT18 would be a means to increase the efficacy of Remdesivir. However, no NUDT18 inhibitors are available to the best of our knowledge.

The importance of intracellular metabolism for efficiency of antivirals is exemplified by the activity of human ITPase with Ribavirin-TP (16). Approximately a third of the human population carries low activity ITPase alleles (16) and it is clear that cellular ITPase activity influences the antiviral efficacy of Ribavirin as well as its adverse effects. Similarly, higher expression of NUDT18 in respiratory epithelial cells in a COVID19 patient, potentially resulting in considerable Remdesivir-TP hydrolysis, may result in lower efficiency of Remdesivir compared to in a patient with lower NUDT18 expression levels. This may explain observed differences in response to Remdesivir treatment between patients.

Here we show that human NUDT18 can catalyze the hydrolysis of the active metabolites of the antivirals Remdesivir and Ribavirin. This novel NUDT18 activity may be clinically relevant and warrants further investigation and emphasizes the need for NUDT18-specific inhibitory chemical probes to be able to investigate the cellular NUDT18 function and role in modulating efficacy of these antiviral drugs.

In summary, we suggest a potential cellular role of NUDT18 as a sanitizer of modified nucleotides, including antiviral triphosphates in the cell.

\section{Data availability}

All data are available from the authors upon request.

\section{Funding}

This work was supported by the European Research Council (TAROX Programme, ERC-695376 to TH), the Swedish Research Council (2015-00162, 2017-06095 to TH and 2018-03406 to P.S.), the Torsten and Ragnar Söderberg Foundation (TH), the Knut and Alice Wallenberg Foundation (KAW2014.0273 to T.H.), the Swedish Cancer Society (CAN2018/0658 to T.H. and 201287 PjF to P.S.), KI funds (2020-02211 to A.S.J), the Alfred Österlund foundation (to P.S), the Åke Olsson foundation for haematological research (2020-00306 to M.M.), and the EU/EFPIA/OICR/McGill/KTH/Diamond Innovative Medicines Initiative 2 Joint Undertaking (EUbOPEN grant no 875510, M.M. and E.J.H.). Funding for open access charge: The Swedish Research Council. 


\section{Acknowledgement}

The authors thank the Protein Science Facility at Karolinska Institutet/SciLifeLab (http://ki.se/psf) for protein production and Mari Kullman Magnusson for excellent laboratory support and Louise Sjöholm for administrative support. We thank Dr Maeve Long for linguistic corrections. We thank the Swedish Research Council, the Swedish Cancer Society, the Knut and Alice Wallenberg Foundation, the Torsten and Ragnar Söderberg Foundation, the Alfred Österlund foundation, Åke Olsson foundation, EUbOPEN and KI funds for financial support.

\section{References}

1. de Wit, E., Feldmann, F., Cronin, J., Jordan, R., Okumura, A., Thomas, T., Scott, D., Cihlar, T. and Feldmann, H. (2020) Prophylactic and therapeutic remdesivir (GS-5734) treatment in the rhesus macaque model of MERS-CoV infection. Proc Natl Acad Sci U S A, 117, 6771-6776.

2. Beigel, J.H., Tomashek, K.M., Dodd, L.E., Mehta, A.K., Zingman, B.S., Kalil, A.C., Hohmann, E., Chu, H.Y., Luetkemeyer, A., Kline, S. et al. (2020) Remdesivir for the Treatment of Covid-19 Final Report. N Engl J Med, 383, 1813-1826.

3. Ngo, B.T., Marik, P., Kory, P., Shapiro, L., Thomadsen, R., Iglesias, J., Ditmore, S., Rendell, M., Varon, J., Dube, M. et al. (2021) The time to offer treatments for COVID-19. Expert Opin Investig Drugs, 1-14.

4. Artese, A., Svicher, V., Costa, G., Salpini, R., Di Maio, V.C., Alkhatib, M., Ambrosio, F.A., Santoro, M.M., Assaraf, Y.G., Alcaro, S. et al. (2020) Current status of antivirals and druggable targets of SARS CoV-2 and other human pathogenic coronaviruses. Drug Resist Updat, 53, 100721.

5. Grein, J., Ohmagari, N., Shin, D., Diaz, G., Asperges, E., Castagna, A., Feldt, T., Green, G., Green, M.L., Lescure, F.X. et al. (2020) Compassionate Use of Remdesivir for Patients with Severe Covid19. N Engl J Med, 382, 2327-2336.

6. $\quad$ Teoh, S.L., Lim, Y.H., Lai, N.M. and Lee, S.W.H. (2020) Directly Acting Antivirals for COVID-19: Where Do We Stand? Front Microbiol, 11, 1857.

7. Agostini, M.L., Andres, E.L., Sims, A.C., Graham, R.L., Sheahan, T.P., Lu, X.T., Smith, E.C., Case, J.B., Feng, J.Y., Jordan, R. et al. (2018) Coronavirus Susceptibility to the Antiviral Remdesivir (GS5734) Is Mediated by the Viral Polymerase and the Proofreading Exoribonuclease. Mbio, 9.

8. Gordon, C.J., Tchesnokov, E.P., Feng, J.Y., Porter, D.P. and Gotte, M. (2020) The antiviral compound remdesivir potently inhibits RNA-dependent RNA polymerase from Middle East respiratory syndrome coronavirus. J Biol Chem, 295, 4773-4779.

9. Sidwell, R.W., Huffman, J.H., Khare, G.P., Allen, L.B., Witkowski, J.T. and Robins, R.K. (1972) Broad-spectrum antiviral activity of Virazole: 1-beta-D-ribofuranosyl-1,2,4-triazole-3carboxamide. Science, 177, 705-706.

10. Reichard, O., Norkrans, G., Fryden, A., Braconier, J.H., Sonnerborg, A. and Weiland, O. (1998) Randomised, double-blind, placebo-controlled trial of interferon alpha- $2 \mathrm{~b}$ with and without ribavirin for chronic hepatitis C. The Swedish Study Group. Lancet, 351, 83-87.

11. Debing, Y., Jochmans, D. and Neyts, J. (2013) Intervention strategies for emerging viruses: use of antivirals. Curr Opin Virol, 3, 217-224.

12. Ascioglu, S., Leblebicioglu, H., Vahaboglu, H. and Chan, K.A. (2011) Ribavirin for patients with Crimean-Congo haemorrhagic fever: a systematic review and meta-analysis. J Antimicrob Chemother, 66, 1215-1222.

13. Dokuzoguz, B., Celikbas, A.K., Gok, S.E., Baykam, N., Eroglu, M.N. and Ergonul, O. (2013) Severity Scoring Index for Crimean-Congo Hemorrhagic Fever and the Impact of Ribavirin and Corticosteroids on Fatality. Clin Infect Dis, 57, 1270-1274. 
14. Kamar, N., Izopet, J., Tripon, S., Bismuth, M., Hillaire, S., Dumortier, J., Radenne, S., Coilly, A., Garrigue, V., D'Alteroche, L. et al. (2014) Ribavirin for Chronic Hepatitis E Virus Infection in Transplant Recipients. New Engl J Med, 370, 1111-1120.

15. Morgenstern, B., Michaelis, M., Baer, P.C., Doerr, H.W. and Cinatl, J. (2005) Ribavirin and interferon-beta synergistically inhibit SARS-associated coronavirus replication in animal and human cell lines. Biochem Bioph Res Co, 326, 905-908.

16. Nystrom, K., Wanrooij, P.H., Waldenstrom, J., Adamek, L., Brunet, S., Said, J., Nilsson, S., WindRotolo, M., Hellstrand, K., Norder, H. et al. (2018) Inosine Triphosphate Pyrophosphatase Dephosphorylates Ribavirin Triphosphate and Reduced Enzymatic Activity Potentiates Mutagenesis in Hepatitis C Virus. J Virol, 92.

17. Fellay, J., Thompson, A.J., Ge, D., Gumbs, C.E., Urban, T.J., Shianna, K.V., Little, L.D., Qiu, P., Bertelsen, A.H., Watson, M. et al. (2010) ITPA gene variants protect against anaemia in patients treated for chronic hepatitis C. Nature, 464, 405-408.

18. Jemth, A.S., Gustafsson, R., Brautigam, L., Henriksson, L., Vallin, K.S.A., Sarno, A., Almlof, I., Homan, E., Rasti, A., Warpman Berglund, U. et al. (2018) MutT homologue 1 (MTH1) catalyzes the hydrolysis of mutagenic O6-methyl-dGTP. Nucleic Acids Res, 46, 10888-10904.

19. Scaletti, E.R., Vallin, K.S., Brautigam, L., Sarno, A., Warpman Berglund, U., Helleday, T., Stenmark, P. and Jemth, A.S. (2020) MutT homologue 1 (MTH1) removes N6-methyl-dATP from the dNTP pool. J Biol Chem, 295, 4761-4772.

20. Valerie, N.C., Hagenkort, A., Page, B.D., Masuyer, G., Rehling, D., Carter, M., Bevc, L., Herr, P., Homan, E., Sheppard, N.G. et al. (2016) NUDT15 Hydrolyzes 6-Thio-DeoxyGTP to Mediate the Anticancer Efficacy of 6-Thioguanine. Cancer Res, 76, 5501-5511.

21. Zhang, S.M., Rehling, D., Jemth, A.S., Throup, A., Landazuri, N., Almlof, I., Gottmann, M., Valerie, N.C.K., Borhade, S.R., Wakchaure, P. et al. (2021) NUDT15-mediated hydrolysis limits the efficacy of anti-HCMV drug ganciclovir. Cell Chem Biol.

22. Takagi, Y., Setoyama, D., Ito, R., Kamiya, H., Yamagata, Y. and Sekiguchi, M. (2012) Human MTH3 (NUDT18) protein hydrolyzes oxidized forms of guanosine and deoxyguanosine diphosphates: comparison with MTH1 and MTH2. J Biol Chem, 287, 21541-21549.

23. Hashiguchi, K., Hayashi, M., Sekiguchi, M. and Umezu, K. (2018) The roles of human MTH1, $\mathrm{MTH} 2$ and $\mathrm{MTH} 3$ proteins in maintaining genome stability under oxidative stress. Mutat Res, 808, 10-19.

24. Carreras-Puigvert, J., Zitnik, M., Jemth, A.S., Carter, M., Unterlass, J.E., Hallstrom, B., Loseva, O., Karem, Z., Calderon-Montano, J.M., Lindskog, C. et al. (2017) A comprehensive structural, biochemical and biological profiling of the human NUDIX hydrolase family. Nat Commun, 8 , 1541.

25. Gad, H., Koolmeister, T., Jemth, A.S., Eshtad, S., Jacques, S.A., Strom, C.E., Svensson, L.M., Schultz, N., Lundback, T., Einarsdottir, B.O. et al. (2014) MTH1 inhibition eradicates cancer by preventing sanitation of the dNTP pool. Nature, 508, 215-221.

26. Baykov, A.A., Evtushenko, O.A. and Avaeva, S.M. (1988) A malachite green procedure for orthophosphate determination and its use in alkaline phosphatase-based enzyme immunoassay. Anal Biochem, 171, 266-270.

27. Sherman, W., Day, T., Jacobson, M.P., Friesner, R.A. and Farid, R. (2006) Novel procedure for modeling ligand/receptor induced fit effects. J Med Chem, 49, 534-553.

28. Sun, D.X. (2020) Remdesivir for Treatment of COVID-19: Combination of Pulmonary and IV Administration May Offer Aditional Benefit. Aaps J, 22.

29. Ting Wang, J.F., Karen Schwartz, Peidong Fan, Michael O. Ports, Adam Kashishian, Gregory T. Notte, Adrian S. Ray and Eisuke Murakami. (2020) Direct Measurement of the Intracellular 
Concentration of 8-Oxo-2'-Deoxyguanosine-5'-Triphosphate by LC-MS/MS. Journal of Bioanalysis \& Biomedicine, 12.

30. Michel, M., Homan, E.J., Wiita, E., Pedersen, K., Almlof, I., Gustavsson, A.L., Lundback, T., Helleday, T. and Berglund, U.W. (2020) In silicoDruggability Assessment of the NUDIX Hydrolase Protein Family as a Workflow for Target Prioritization. Front Chem, 8.

31. Zhang, S.M., Desroses, M., Hagenkort, A., Valerie, N.C.K., Rehling, D., Carter, M., Wallner, O., Koolmeister, T., Throup, A., Jemth, A.S. et al. (2020) Development of a chemical probe against NUDT15. Nat Chem Biol, 16, 1120-1128.

32. Loving, K.A. (2014) Structure-Based Druggability Assessment of the Mammalian Structural Proteome with Inclusion of Light Protein Flexibility (vol 10, e1003741, 2014). Plos Comput Biol, 10.

33. Holm, L. and Rosenstrom, P. (2010) Dali server: conservation mapping in 3D. Nucleic Acids Res, 38, W545-549.

34. Waz, S., Nakamura, T., Hirata, K., Koga-Ogawa, Y., Chirifu, M., Arimori, T., Tamada, T., Ikemizu, S., Nakabeppu, Y. and Yamagata, Y. (2017) Structural and Kinetic Studies of the Human Nudix Hydrolase MTH1 Reveal the Mechanism for Its Broad Substrate Specificity. J Biol Chem, 292, 2785-2794.

\section{Figure Legends}

Figure 1. Structure, intracellular metabolism and mode of action of Remdesivir

Figure 2. (A) Hydrolysis activity of MTH1, NUDT15, NUDT18, NUDT5 and NUDT9 (200 nM) with $100 \mu \mathrm{M}$ Remdesivir-TP was tested in assay buffer ( $20 \mathrm{mM}$ TrisAcetate pH 8.0, $40 \mathrm{mM} \mathrm{NaCl}, 10 \mathrm{mM} \mathrm{MgAc}, 1 \mathrm{mM}$ DTT, $0.05 \%$ Tween 20) by incubation at $22{ }^{\circ} \mathrm{C}$ for 30 minutes. Formed Pi was detected by addition of malachite green reagent and measurement of absorbance at $630 \mathrm{~nm}$. (B) Activity of $200 \mathrm{nM} \mathrm{MTH1}$, NUDT15, NUDT18, NUDT5, was also tested in presence of PPase $(0.2 \mathrm{U} / \mathrm{ml})$ that converts formed PPi to Pi. (C) Activity of the human pyrophoshatases ITPase, dUTPase and dCTPase with $100 \mu \mathrm{M}$ Remdesivir-TP was assayed in presence of PPase was assayed and compared to activity of NUDT18 with and without PPase and to NUDT18 activity with $100 \mu \mathrm{M}$ 8-oxo-dGDP. (D) Hydrolysis products of NUDT18 catalyzed hydrolysis of Remdesivir-TP in presence and absence of NUDT18.

Figure 3. Hydrolysis activity of $100 \mathrm{nM}$ NUDT18 with $100 \mu \mathrm{M}$ Ribavirin-TP or Remdesivir-TP, in presence and absence of $0.2 \mathrm{U} / \mathrm{ml} \mathrm{E}$. coli PPase, was monitored in assay buffer $(20 \mathrm{mM}$ TrisAcetate pH 8.0, $40 \mathrm{mM}$ $\mathrm{NaCl}, 10 \mathrm{mM}$ Magnesium Acetate, $1 \mathrm{mM} \mathrm{DTT}, 0.05 \%$ Tween20) by incubation at $22^{\circ} \mathrm{C}$ for 30 minutes. Hydrolysis activity of $10 \mathrm{nM}$ NUDT18 was assessed with $100 \mu \mathrm{M}$ Ribavirin-TP in assay buffer with E. coli PPase $(0.2 \mathrm{U} / \mathrm{ml})$ by incubating reactions at $22{ }^{\circ} \mathrm{C}$ for 30 minutes. Formed Pi was detected by addition of malachite green reagent and measurement of absorbance at $630 \mathrm{~nm}$.

Figure 4. Enzyme saturation curves of NUDT18 with (A) Remdesivir-TP, (B) Ribavirin-TP and (C) 8-oxodGDP. (D) Specific activity of $20 \mathrm{nM}$ NUDT18 with $100 \mu \mathrm{M}$ of triphopshates of the antivirals Ganciclovir, Aciclovir, Sofosbuvir and the cytostatic drug Gemcitabine was tested by incubation for $30 \mathrm{~min}$ at $22{ }^{\circ} \mathrm{C}$ in 
assay buffer ( $20 \mathrm{mM}$ TrisAcetate $\mathrm{pH}$ 8.0, $40 \mathrm{mM} \mathrm{NaCl}, 10 \mathrm{mM}$ MgAcetate, $1 \mathrm{mM}$ DTT and 0.01\% Tween 20), in absence and presence of E. coli PPase $0.2 \mathrm{U} / \mathrm{ml}$ ). Formed Pi was detected using addition of a malachite green reagent followed by measurement of absorbance at $630 \mathrm{~nm}$. Figure shows formed [Pi] $(\mu \mathrm{M})$ per [NUDT18] (nM). (E) Enzyme saturation curves of NUDT18 with Sofosbuvir-TP, Aciclovir-TP and dGTP. (F) Kinetic parameters of NUDT18 with Remdesivir-TP, Ribavirin-TP, 8-oxodGDP, Aciclovir-TP, Sofosbuvir-TP and dGTP. Presented is average and standard deviation of kinetic parameters determined from two independent experiments and with data points performed in duplicate.

Figure 5. Relative catalytic efficiency and turnover numbers of NUDT18 with tested substrates and their chemical structures

Figure 6. Inhibition of NUDIX enzymes by Remdesivir and its metabolites. MTH1 and NUDT15 was tested for inhibition by $100 \mu \mathrm{M}$ Remdesivir-TP, Remdesivir or Remdesivir metabolite (GS441524) in an activity assay using $100 \mu \mathrm{M}$ dGTP as substrate and $10 \mathrm{nM}$ NUDT15 or MTH1. The potency of Remdesivir and Remdesivir metabolite (GS441524) to inhibit NUDT18 was tested in an assay using $100 \mu \mathrm{M}$ 8-oxodGDP as substrate and using 100 nM NUDT18. NUDT15 is modestly inhibited by Remdesivir and activity of all three enzymes are reduced by approximately $20 \%$ in presence of the Remdesivir metabolite (GS441524). 
bioRxiv preprint doi: https://doi.org/10.1101/2021.11.16.468802; this version posted November 17, 2021. The copyright holder for this preprint (which was not certified by peer review) is the author/funder, who has granted bioRxiv a license to display the preprint in perpetuity. It is made available under aCC-BY-NC-ND 4.0 International license.

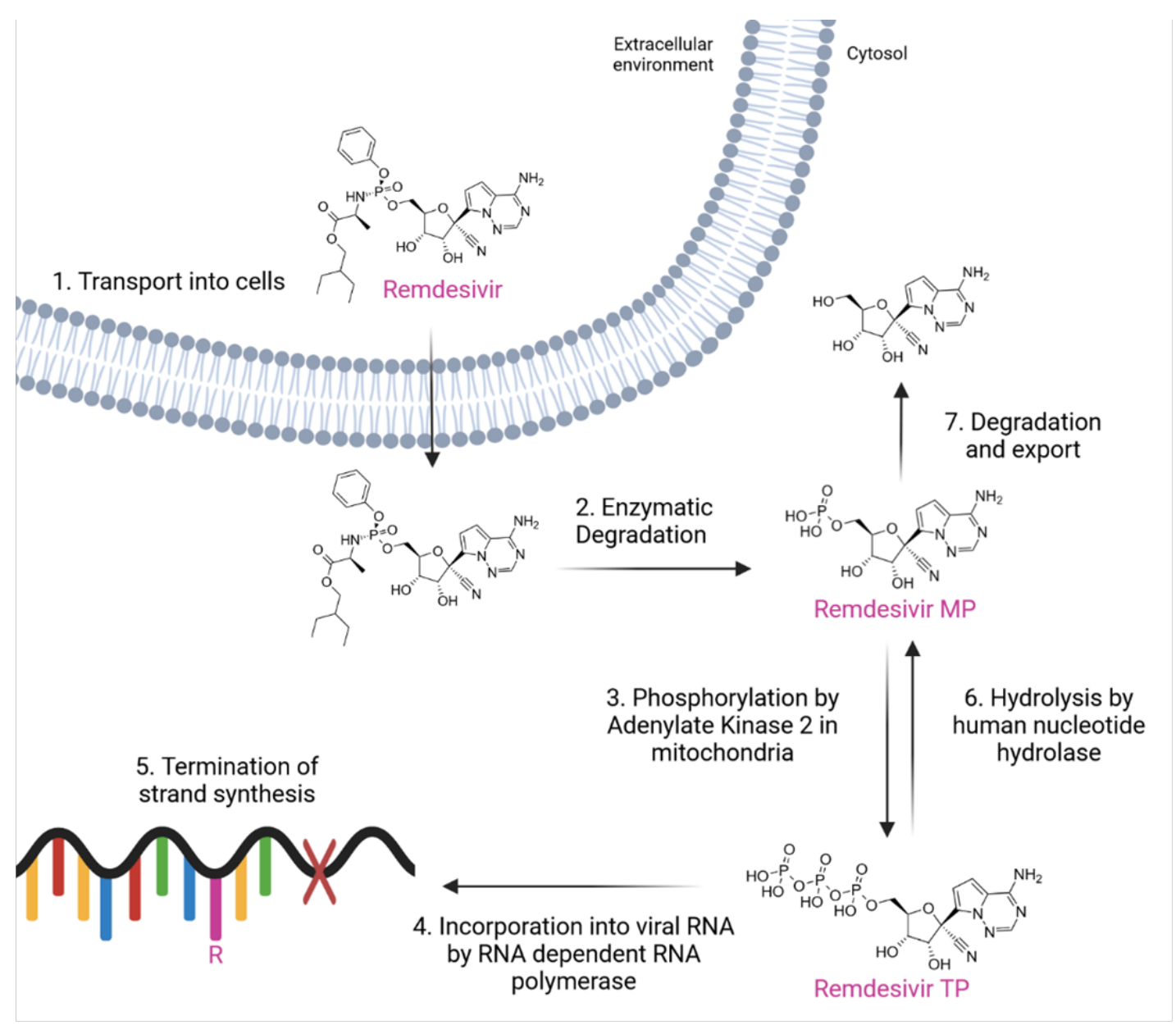

Figure 1. Structure, intracellular metabolism and mode of action of Remdesivir 
bioRxiv preprint doi: https://doi.org/10.1101/2021.11.16.468802; this version posted November 17,2021 . The copyright holder for this preprint (which was not certified by peer review) is the author/funder, who has granted bioRxiv a license to display the preprint in perpetuity. It is made available under aCC-BY-NC-ND 4.0 International license.

A

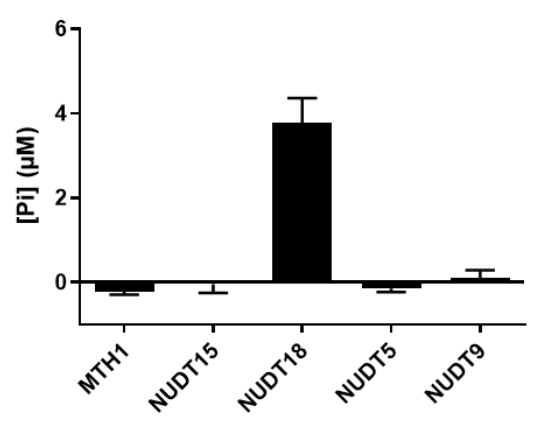

D
B

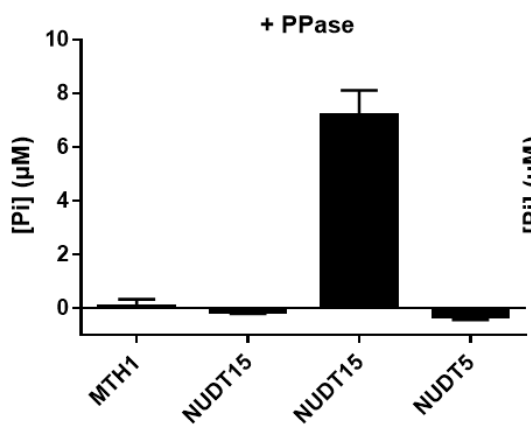

C

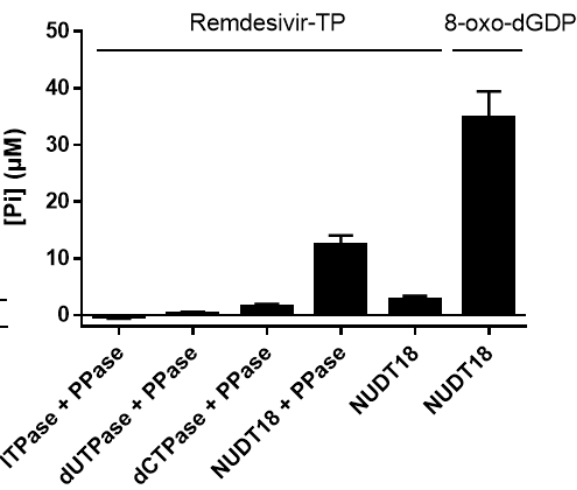

Remdesivir-TP + $\mathrm{H}_{2} \mathrm{O} \longrightarrow$ Remdesivir-DP + Pi

Remdesivir-TP $+\mathbf{H}_{\mathbf{2}} \mathbf{O} \stackrel{\text { NUDT18 }}{\longrightarrow}$ Remdesivir-MP + PPi $\stackrel{\text { PPase }}{\longrightarrow}$ Remdesivir-MP + 2Pi

Figure 2. (A) Hydrolysis activity of MTH1, NUDT15, NUDT18, NUDT5 and NUDT9 (200 nM) with $100 \mu \mathrm{M}$ Remdesivir-TP was tested in assay buffer $(20 \mathrm{mM}$ TrisAcetate $\mathrm{pH}$ 8.0, $40 \mathrm{mM} \mathrm{NaCl}, 10 \mathrm{mM} \mathrm{MgAc}, 1 \mathrm{mM}$ DTT, $0.05 \%$ Tween 20 ) by incubation at $22{ }^{\circ} \mathrm{C}$ for 30 minutes. Formed Pi was detected by addition of malachite green reagent and measurement of absorbance at $630 \mathrm{~nm}$. (B) Activity of $200 \mathrm{nM} \mathrm{MTH1,} \mathrm{NUDT15,} \mathrm{NUDT18,} \mathrm{NUDT5,}$ was also tested in presence of PPase $(0.2 \mathrm{U} / \mathrm{ml})$ that converts formed PPi to Pi. (C) Activity of the human pyrophoshatases ITPase, dUTPase and dCTPase with $100 \mu \mathrm{M}$ Remdesivir-TP was assayed in presence of PPase was assayed and compared to activity of NUDT18 with and without PPase and to NUDT18 activity with $100 \mu \mathrm{M} 8$ oxo-dGDP. (D) Hydrolysis products of NUDT18 catalyzed hydrolysis of Remdesivir-TP in presence and absence of NUDT18. 
bioRxiv preprint doi: https://doi.org/10.1101/2021.11.16.468802; this version posted November 17, 2021. The copyright holder for this preprint (which was not certified by peer review) is the author/funder, who has granted bioRxiv a license to display the preprint in perpetuity. It is made available under aCC-BY-NC-ND 4.0 International license.

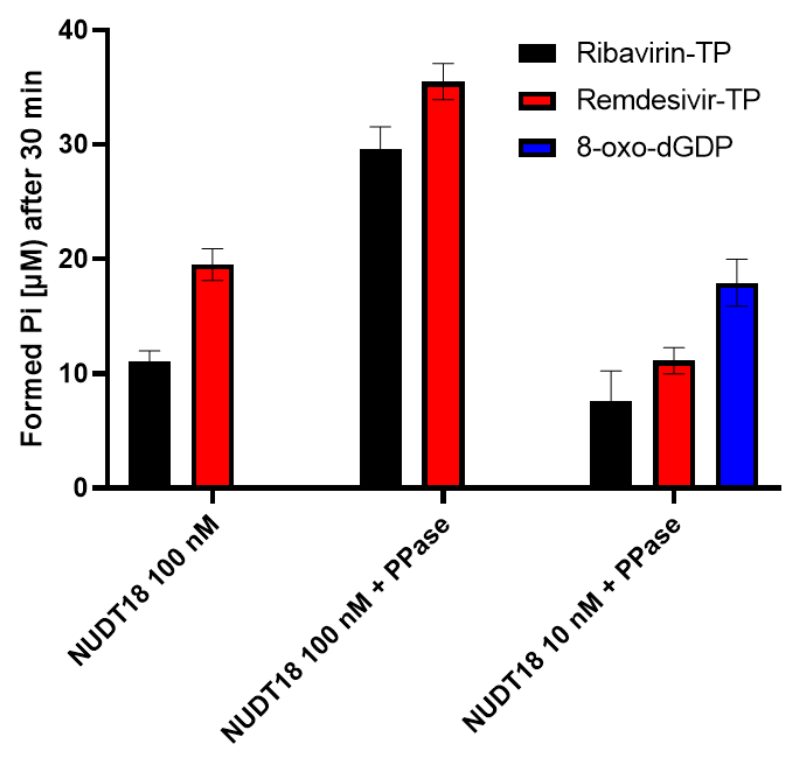

Figure 3. Hydrolysis activity of $100 \mathrm{nM}$ NUDT18 with $100 \mu \mathrm{M}$ Ribavirin-TP or Remdesivir-TP, in presence and absence of $0.2 \mathrm{U} / \mathrm{ml}$ E. coli PPase, was monitored in assay buffer (20 mM TrisAcetate pH 8.0, $40 \mathrm{mM} \mathrm{NaCl}, 10 \mathrm{mM}$ Magnesium Acetate, $1 \mathrm{mM}$ DTT, $0.05 \%$ Tween20) by incubation at $22{ }^{\circ} \mathrm{C}$ for 30 minutes. Hydrolysis activity of 10 nM NUDT18 was assessed with $100 \mu \mathrm{M}$ Ribavirin-TP in assay buffer with E. coli PPase (0.2 U/ml) by incubating reactions at $22^{\circ} \mathrm{C}$ for 30 minutes. Formed Pi was detected by addition of malachite green reagent and measurement of absorbance at $630 \mathrm{~nm}$. 
bioRxiv preprint doi: https://doi.org/10.1101/2021.11.16.468802; this version posted November 17,2021 . The copyright holder for this preprint (which was not certified by peer review) is the author/funder, who has granted bioRxiv a license to display the preprint in perpetuity. It is made available under aCC-BY-NC-ND 4.0 International license.

A

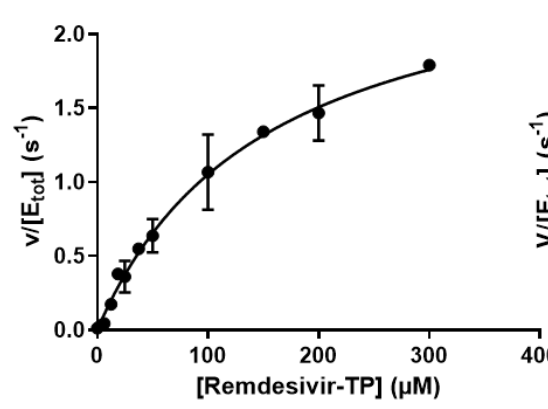

D

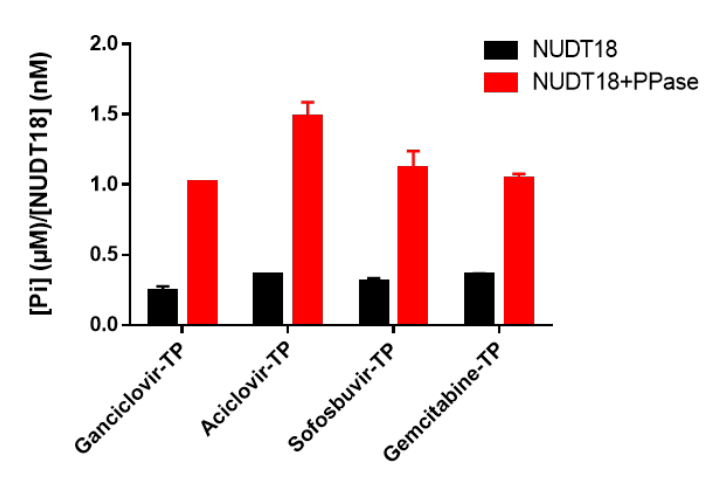

B

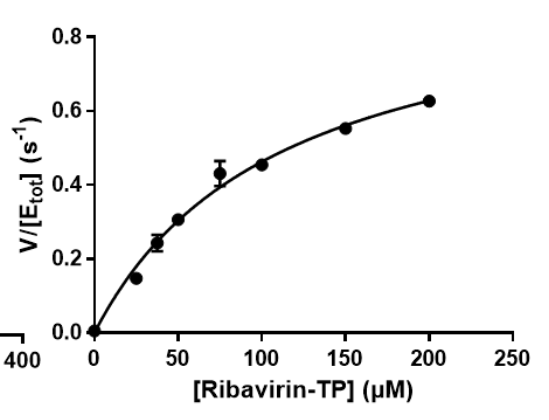

C

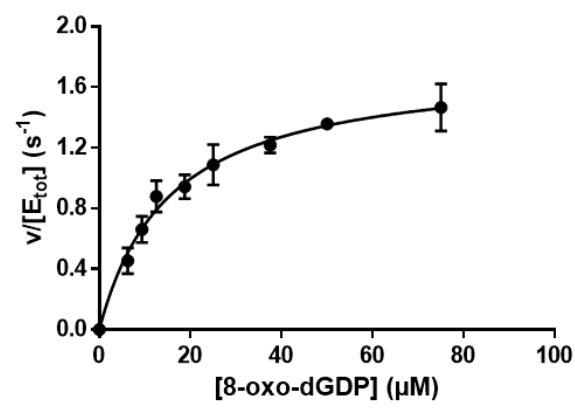

F

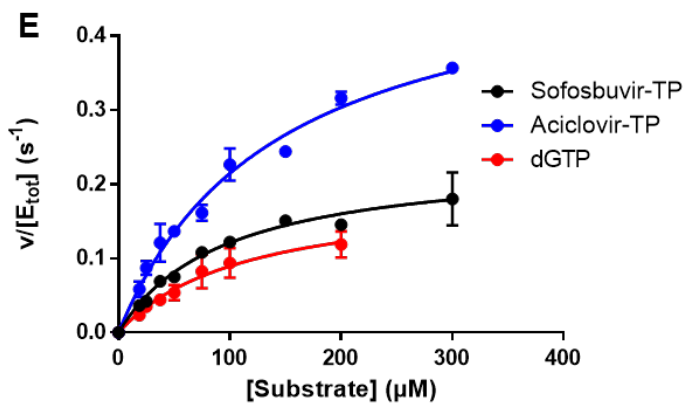

Substrate

\begin{tabular}{lcccccc}
\hline & \multicolumn{5}{c}{ Substrate } \\
\cline { 2 - 6 } & $\mathbf{d G T P}$ & Sofosbuvir-TP & Aciclovir-TP & Remdesivir-TP & Ribavirin-TP & 8-oxo-dGDP \\
\cline { 2 - 6 } $\mathbf{K}_{\text {cat }}\left(\mathbf{s}^{-1}\right)$ & $0.20 \pm 0.07$ & $0.24 \pm 0.05$ & $0.53 \pm 0.01$ & $2.6 \pm 0.1$ & $0.98 \pm 0.03$ & $1.8 \pm 0.2$ \\
$\mathbf{K}_{\mathrm{m}}(\boldsymbol{\mu M})$ & $117 \pm 26$ & $97 \pm 22$ & $146 \pm 1.0$ & $156 \pm 60$ & $111 \pm 5$ & $16.5 \pm 0.8$ \\
$\mathbf{K}_{\text {cat }} / \mathbf{K}_{\mathrm{m}}\left(\mathbf{M}^{-1} \mathbf{s}^{-1}\right)$ & $1680 \pm 190$ & $2530 \pm 70$ & $3620 \pm 90$ & $17,700 \pm 5800$ & $8,808 \pm 63$ & $109,800 \pm 6,500$ \\
\hline
\end{tabular}

Figure 4. Enzyme saturation curves of NUDT18 with (A) Remdesivir-TP, (B) Ribavirin-TP and (C) 8-oxo-dGDP. (D) Specific activity of $20 \mathrm{nM}$ NUDT18 with $100 \mu \mathrm{M}$ of triphopshates of the antivirals Ganciclovir, Aciclovir, Sofosbuvir and the cytostatic drug Gemcitabine was tested by incubation for $30 \mathrm{~min}$ at $22^{\circ} \mathrm{C}$ in assay buffer ( $20 \mathrm{mM}$ TrisAcetate $\mathrm{pH} 8.0,40 \mathrm{mM} \mathrm{NaCl}, 10$ $\mathrm{mM} \mathrm{MgAcetate,} 1 \mathrm{mM}$ DTT and 0.01\% Tween 20), in absence and presence of E. coli PPase $0.2 \mathrm{U} / \mathrm{ml}$ ). Formed Pi was detected using addition of a malachite green reagent followed by measurement of absorbance at $630 \mathrm{~nm}$. Figure shows formed [Pi] $(\mu \mathrm{M})$ per [NUDT18] (nM). (E) Enzyme saturation curves of NUDT18 with Sofosbuvir-TP, Aciclovir-TP and dGTP. (F) Kinetic parameters of NUDT18 with Remdesivir-TP, Ribavirin-TP, 8-oxodGDP, Aciclovir-TP, Sofosbuvir-TP and dGTP. Presented is average and standard deviation of kinetic parameters determined from two independent experiments and with data points performed in duplicate. 
bioRxiv preprint doi: https://doi.org/10.1101/2021.11.16.468802; this version posted November 17, 2021. The copyright holder for this preprint (which was not certified by peer review) is the author/funder, who has granted bioRxiv a license to display the preprint in perpetuity. It is made available under aCC-BY-NC-ND 4.0 International license.

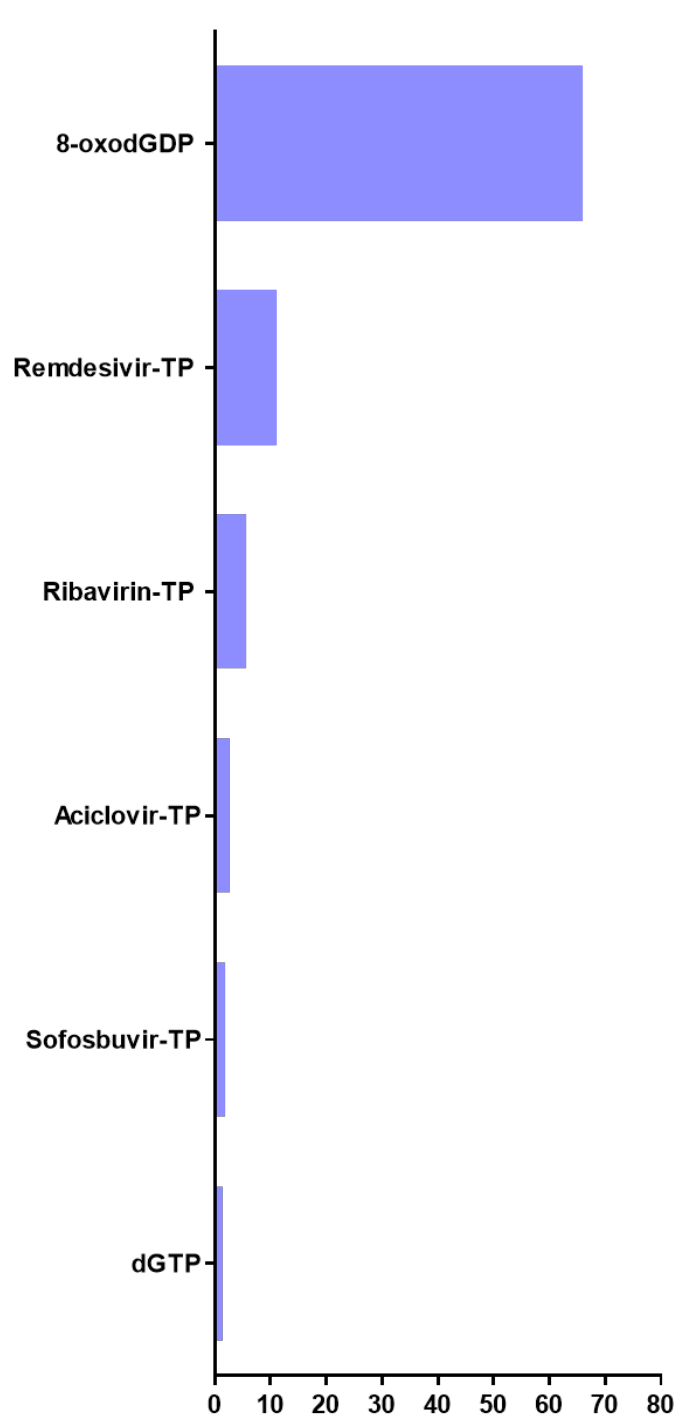

Relative catalytic efficiency $\left(k_{\text {cat }} / K_{m}\right)$
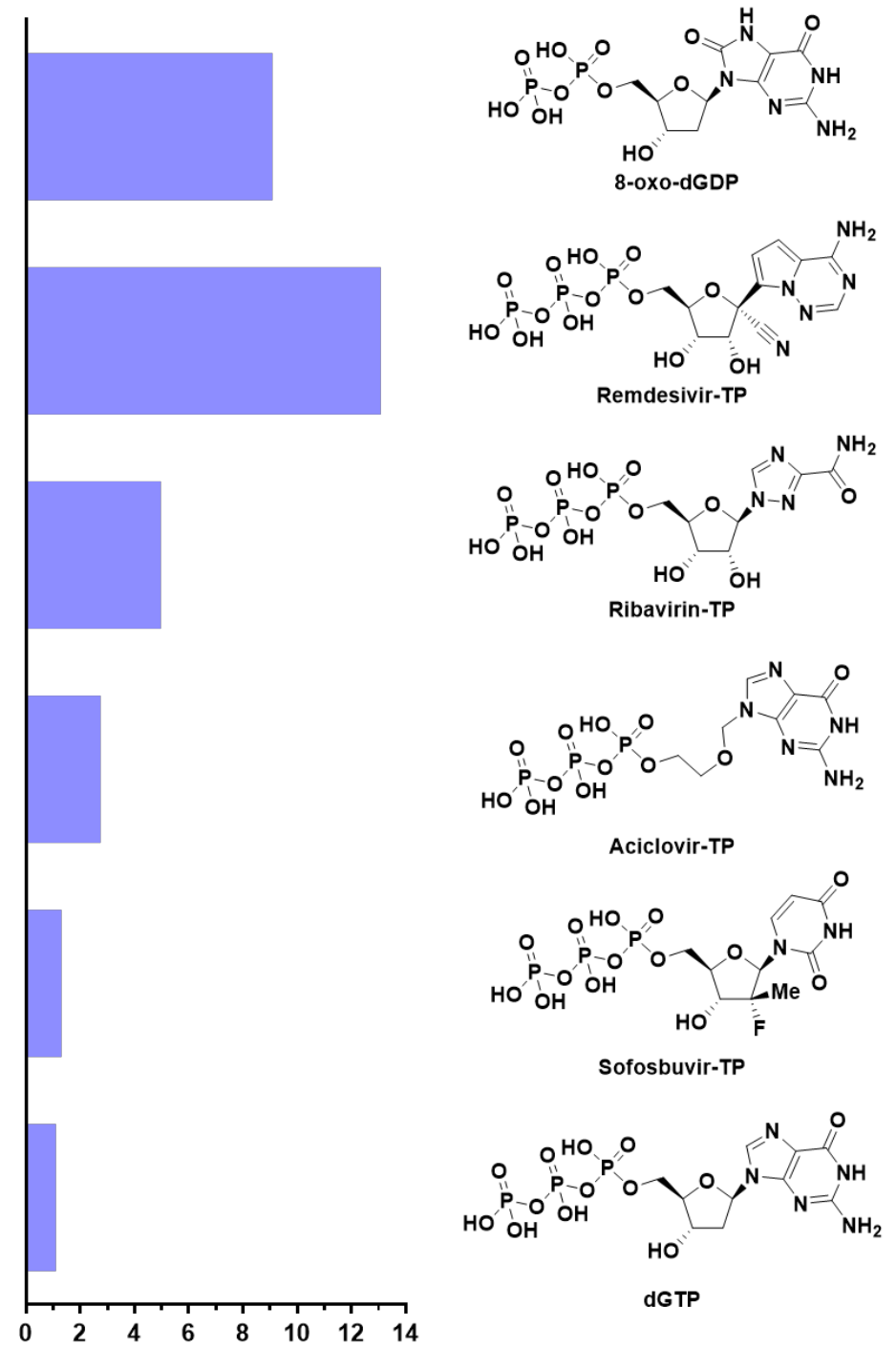

Relative turnover $\left(\mathbf{k}_{\text {cat }}\right)$

Figure 5. Relative catalytic efficiency and turnover numbers of NUDT18 with tested substrates and their chemical structures. 
bioRxiv preprint doi: https://doi.org/10.1101/2021.11.16.468802; this version posted November 17, 2021. The copyright holder for this preprint (which was not certified by peer review) is the author/funder, who has granted bioRxiv a license to display the preprint in perpetuity. It is made available under aCC-BY-NC-ND 4.0 International license.

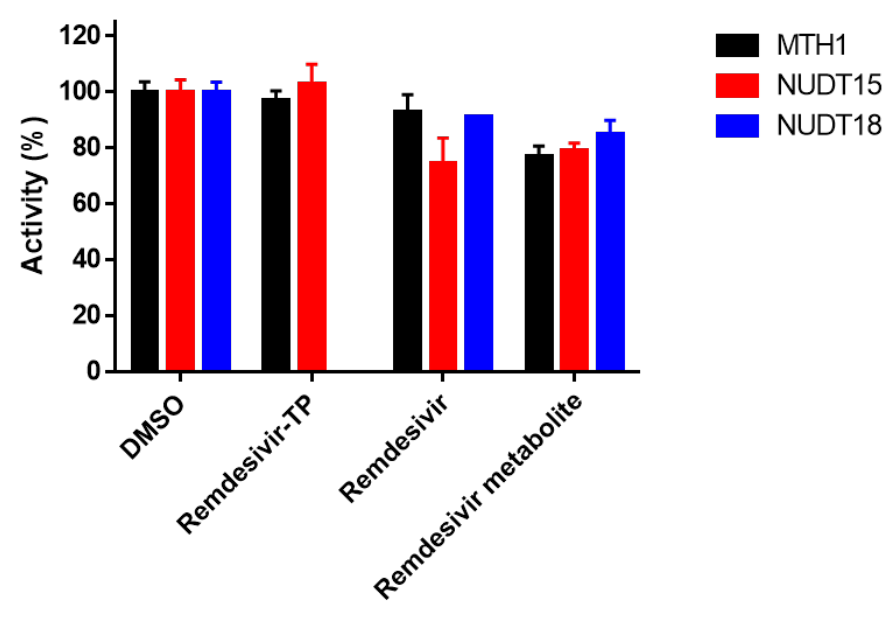

Figure 6. Inhibition of NUDIX enzymes by Remdesivir and its metabolites. MTH1 and NUDT15 was tested for inhibition by $100 \mu \mathrm{M}$ Remdesivir-TP, Remdesivir or Remdesivir metabolite (GS441524) in an activity assay using $100 \mu \mathrm{M}$ dGTP as substrate and $10 \mathrm{nM}$ NUDT15 or MTH1. The potency of Remdesivir and Remdesivir metabolite (GS441524) to inhibit NUDT18 was tested in an assay using $100 \mu \mathrm{M}$ 8-oxo-dGDP as substrate and using $100 \mathrm{nM}$ NUDT18. NUDT15 is modestly inhibited by Remdesivir and activity of all three enzymes are reduced by approximately $20 \%$ in presence of the Remdesivir metabolite (GS441524). 
bioRxiv preprint doi: https://doi.org/10.1101/2021.11.16.468802; this version posted November 17, 2021. The copyright holder for this preprint (which was not certified by peer review) is the author/funder, who has granted bioRxiv a license to display the preprint in perpetuity. It is made available under aCC-BY-NC-ND 4.0 International license.
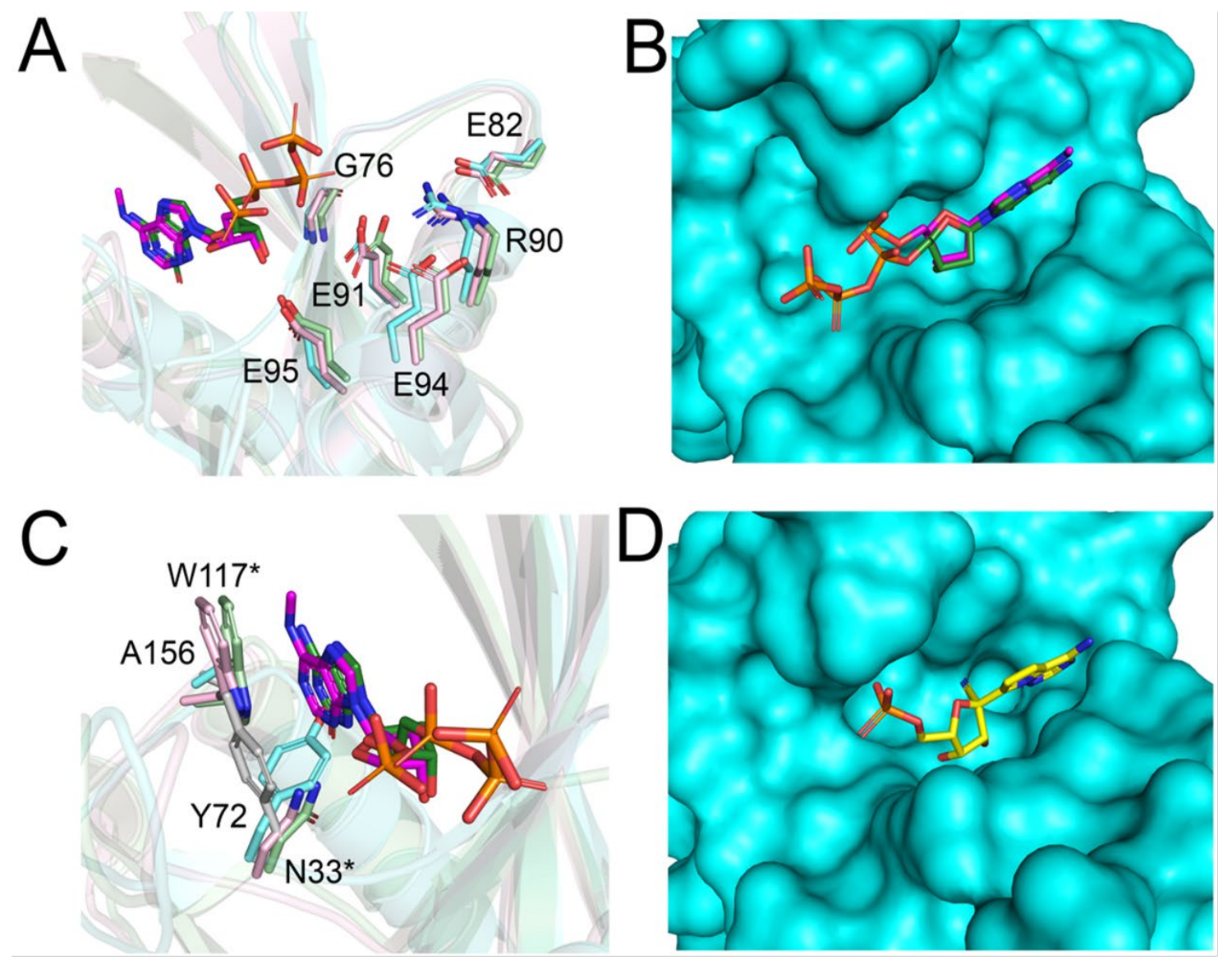

Supplementary Figure 1. Structural comparison of hNUDT18 with hMTH1. (A) Superposition of the hNUDT18 nucleotidase domain (cyan, residues 36-179, PDB ID: 3gg6) with hMTH1 bound to N6-methyl-dAMP (light pink, PDB ID: 6qvo, (19) and hMTH1 bound to 2OH-dATP (pale green, PDB ID: 5ghq, (34). N6-methyl-dAMP and 2OH-dATP are shown as magenta and dark green stick models, respectively. Residues from the NUDIX box motif from MTH1 and NUDT18 that coordinate magnesium, and therefore facilitate substrate hydrolysis, are shown as sticks. Numbering corresponds to residues in the NUDT18 sequence. (B) Surface representation of NUDT18 (cyan) superimposed with hMTH1-N6-methyl-dAMP and hMTH12OH-dATP, showing NUDT18 has a shallow binding pocket. (C) Binding pocket surrounding the adenine base. A tryptophan residue (W117*) from hMTH1 involved in an important pi-stacking interaction is highlighted. Asterisks represent residues from the hMTH1 sequence. The residue Y72 in hNUDT18 needs to reposition (shown in grey) in order to accommodate the adenine base in the binding pocket. (D) Surface representation showing the nucleotide binding pocket after repositioning of Y72. Remdesvir-MP (yellow stick representation) has been positioned in the binding pocket assuming a similar binding mode to N6-methyl-dAMP and 2OH-dATP in the hMTH1 structures. 